\title{
CAMPUR DAN ALIH KODE PADA POLA KOMUNIKASI ANTAR DOSEN DAN MAHASISWA DI LNGKUNGAN UNIKOM DALAM APLIKASI MEDIA SOSIAL - KAIIAN SOSIOLINGUISTIK
}

\author{
ASIH PRIHANDINI, M.RAYHAN BUSTAM, NUNGKI HERIYATI \\ Program Studi Sastra Inggris, Fakultas Sastra \\ Universitas Komputer Indonesia
}

Penelitian yang berjudul "Campur dan Alih Kode pada Pola Komunikasi antar Dosen dan Mahasiswa di Lingkungan UNIKOM dalam Aplikasi Media Sosial: Kajian Sosiolinguistik" ini merupakan sebuah penelitian lanjutan dari penelitian yang telah dilakukan sebelumnya yang berjudul: "Alih Kode dan Campur Kode pada Pola Komunikasi Dosen UNIKOM di Aplikasi Kuliah Online Unikom: Kajian Sosiolinguistik". Penelitian ini bertujuan untuk mendeskripsikan jenis dan bentuk alih dan campur kode pada pola komunikasi antar dosen dan mahasiswa UNIKOM dalam aplikasi media sosial, dan faktor yang mempengaruhinya, serta dampak yang ditimbulkan oleh pola komunikasi tersebut. Adapun yang menjadi subjek penelitian ini adalah kode atau bahasa yang digunakan oleh dosen-dosen dan mahasiswa UNIKOM di aplikasi media sosial, sedangkan objeknya adalah campur dan alih kode pada ujaran yang diungkapkan dosen-dosen dan mahasiswa tersebut.

Teknik pengumpulan data yang digunakan pada penelitian ini adalah purposive sampling; yakni mengumpulkan sampel data yang berisikan kasus-kasus alih kode dan campur kode dengan tujuan untuk mengetahui karakteristik jenis, bentuk, faktor, dan dampak pemakaian alih kode dan campur kode. Data yang dikumpulkan, kemudian dipilah berdasarkan kasus-kasus alih kode dan campur kode yang terdapat di dalamnya, lalu, dianalisis dengan teknik analisis deskriptif sesuai dengan konteksnya.

Penelitian ini diharapkan dapat memberikan kontribusi pemahaman tentang campur kode dan alih kode, terutama dalam mendeskripsikan jenis, faktor, dan dampaknya dalam kegiatan berbahasa sehari-hari, Adapun tujuan jangka panjang, diharapkan penelitian ini dapat memberikan pencerahan tentang pola komunikasi yang efektif, terutama terhadap komunikasi antara dosen dan mahasiswa sebagai masyarakat akademis yang terkadang memerlukan penyesuaian pola dan cara berbahasa tertentu.

Selain itu, penelitian ini mempunyai target khusus yakni diharapkan dapat digunakan sebagai salah satu bahan pembelajaran kepada dosen dan mahasiswa ketika melakukan kegiatan belajar mengajar mengenai berbahasa, misalnya yang berhubungan dengan percakapan atau dialog, serta penggunaannya dalam masyarakat berdasarkan bentuk dan fungsi yang sesuai.

Keywords : alih kode, campur kode, media sosial 


\section{PENDAHULUAN}

Dewasa ini perkembangan teknologi telah merambah ke segala aspek dan lapisan masyarakat. Hal tersebut membawa dampak terjadinya banyak perubahan termasuk diantaranya di lingkungan pendidikan seperti dalam proses belajar mengajar. Dalam hal ini teknologi telah mengakibatkan terbentuknya pola komunikasi antara dosen dan mahasiswa.

Penelitian tentang penggunaan alih kode (bahasa) dan campur kode dengan menggunakan media kuliah online sebagai salah satu bentuk aplikasi teknologi ini telah dilakukan. Hasil yang diperoleh adalah bagaimana peralihan dan percampuran kode tersebut terjadi dalam komunikasi searah dari dosen ke mahasiswa. Dengan menggunakan beberapa macam bentuk peralihan dan pecampuran, kode tersebut ditemukan dalam lingkungan masyarakat pendidikan yang multilingual, yaitu bahasa Indonesia, bahasa Inggris dan bahasa Sunda.

Seiring dengan keberadaan masyarakat yang multilingual dan kemajuan teknologi yang muncul di segala lapisan tersebut, ditenggarai adanya pola komunikasi yang terbentuk antara dosen dan mahasiswa dengan menggunakan media sosial, seperti whats up atau line, sebagai media penghubung di luar jam perkuliahan. Komunikasi dilakukan dua arah (dari dosen ke mahasiswa dan sebaliknya) dengan berbagai jenis peralihan atau percampuran kode yang digunakan disertai dengan faktor yang melatar belakanginya.

Berkaitan dengan uraian di atas, pola komunikasi antara dosen dan mahasiswa di UNIKOM dengan menggunakan alih kode dan campur kode dalam aplikasi media sosial menjadi hal yang perlu dikaji untuk melihat jenis bentuk dan faktor penyebab alih kode atau campur kode tersebut terjadi. Kajian ini diharapkan dapat mengobservasi keefektifan komunikasi antara dosen dan mahasiswa.

\section{TINJAUAN PUSTAKA}

\section{Pengertian Alih Kode dan Campur Kode}

Paul Ohoiwutun di dalam bukunya Sosiolinguistik: Memahami Bahasa dalam Konteks Masyarakat dan Kebudayaan (2007:71) mengungkapkan bahwa alih kode merupakan peralihan pemakaian dari suatu bahasa atau dialek ke bahasa atau dialek lainnya. Adapun penyebab alih bahasa ini terjadi adalah karena adanya perubahan sosiokultural dalam situasi berbahasa. Perubahan tersebut mencakup faktor-faktor seperti hubungan antara pembicara dan pendengar, variasi bahasa, tujuan berbicara, topik yang dibahas, waktu dan tempat berbincang. Lebih lanjut, Chloros (2009:4) mengungkapkan bahwasanya alih kode cenderung terjadi pada individu yang bilingual dan ataupun di tengah-tengah masyarakat yang bilingual, yakni masyarakat yang menggunakan bahasa-bahasa yang berlainan (ragam bahasa) yang artinya memakai lebih dari satu bahasa untuk berkomunikasi.

Berkaitan dengan ragam bahasa, Indonesia merupakan salah satu negara yang multilingual. Hal ini disebabkan oleh banyaknya suku di Indonesia; di mana setiap suku tersebut memiliki satu atau lebih bahasa yang digunakan oleh masyarakatnya. Hal ini berdampak terhadap seringnya terjadi pengalihan kode dari bahasa nasional, bahasa Indonesia, ke bahasa daerah maupun sebaliknya. Ditambah lagi, dengan sistem pendidikan di Indonesia, yang memasukkan pelajaran bahasa Indonesia, bahasa daerah, dan bahasa internasional (umumnya bahasa Inggris) sebagai pelajaran yang wajib untuk dipelajari di sekolah. Hal tersebut jelas berdampak terhadap penggunaan bahasa dalam proses komunikasi dan interaksi. Penggunaan ragam bahasa ini ditemukan dalam segala tindak bahasa, baik lisan 
maupun tulisan, dan penggunaan yang acap terjadi adalah pencampuran atau pengalihan dari bahasa tertentu ke bahasa lainnya, seperti: dari bahasa Indonesia ke bahasa daerah, dari bahasa Indonesia ke bahasa asing, dan dari bahasa daerah ke bahasa asing, maupun sebaliknya.

Berkaitan dengan alih kode, dikenal juga istilah campur kode. Ohoiwutun (2007:69) mengungkapkan bahwa campur kode merupakan gejala di mana fenomena dijumpainya suatu kekacauan atau interferensi bahasa (performance interference) yang berbentuk penggunaan unsur-unsur dari suatu bahasa tertentu dalam satu kalimat atau wacana bahasa lain. Terdapat sedikit perbedaan di antara alih kode dan campur kode. Menurut Ritchie dan Bhatia (2004:337) alih kode berada di tataran intersentential (antar kalimat), sedangkan campur kode ada di tataran intrasentential yakni morfem, kata, frasa, dan klausa yang ada di dalam satu kalimat.

Berkaitan dengan penelitian ini, mengenai perbedaan alih kode dan campur kode penulis mengambil teori dari Poplack (1980), yang dikutip oleh Suzanne Romaine dalam artikelnya Language-Contact Studies (2004:53), diungkapkan bahwa alih kode dibedakan menjadi tiga jenis, yaitu: alih kode tag (tag-switching), alih kode antar kalimat (inter-sentential) dan alih kode intra kalimat (intra-sentential).

Mengenai alih kode intra kalimat, Romaine menjelaskan bahwa "Intra-sentential switching involves switching within the boundaries of a clause or sentence, as well as within word boundaries" (2004:53). Pengertian tersebut sejalan dengan pengertian campur kode yang diungkapkan oleh Ohoiwutun. Oleh karena itu, penulis berkesimpulan bahwasanya campur kode juga merupakan salah satu jenis alih kode, yakni alih kode intra-sentential.

\section{Jenis Alih Kode dan Campur Kode}

Seperti yang telah dijelaskan di atas, terdapat tiga jenis alih kode; alih kode tag (tag-switching), alih kode antar kalimat (inter-sentential) dan alih kode intra kalimat (intra-sentential) atau yang dikenal juga dengan campur kode. Adapun penjelasan mengenai jenis-jenis tersebut dan berbagai aspek yang berkaitan dengan hal tersebut akan disajikan pada sub bab berikut.

\section{a. Alih Kode Tag (Tag-Switching)}

Alih kode tag merupakan alih kode yang terjadi pada suatu ujaran dalam bahasa tertentu dengan menyisipkan tag atau yang dikenal dengan istilah 'pengukuh' dari bahasa yang lain. Hal ini seperti terlihat pada kutipan berikut:

"Tag-switching involves the insertion of a tag in one language into an utterance which is otherwise entirely in the other language, e. g. you know, I mean, etc" (Romaine, 2004:53).

Dalam kutipan tersebut, Romaine mencontohkan beberapa tag dalam bahasa Inggris, seperti: you know dan I mean.

Untuk lebih memahami penggunaan alih kode tag tersebut, perhatikan contoh berikut: "Saya kurang paham masalahnya, saya harus nanya dulu ke Ani, you know?". Di sini, penutur mengungkapkan ujaran dalam bahasa Indonesia dan menyisipkan tag di akhir ujarannya yakni: 'ýou know?'. Penggunaan tag tersebut walaupun disertai dengan tanda tanya, tapi fungsinya bukan untuk menanyakan kepada mitra tutur, akan tetapi berfungsi sebagai pengukuh ujaran yang disampaikan sebelumnya.

\section{b. Alih Kode Antar Kalimat (Inter-Sentential Switching)}

Alih kode antar kalimat secara sederhana didefinisikan sebagai alih kode yang terjadi dari satu bahasa ke bahasa lain pada kalimat yang berbeda. Namun, lebih detil, Romaine mengungkapkan sebagai berikut: "Inter-sentential switching involves a switch 
at a clause or sentence boundary, where each clause or sentence is in one language or another" (Romaine, 2004:53).

Kutipan tersebut menjelaskan bahwa alih kode antar kalimat tidak hanya melibatkan antar kalimat, tapi juga bisa melibatkan batas klausa.

Untuk lebih memahami penggunaan alih kode antar kalimat, perhatikan contoh berikut: (a) "I know him well. Dia orang yang baik, kok.", (b) "Seharusnya kalian udah tau bahwa grammar is the most difficult subject!" Dari kedua contoh dapat dilihat, pada contoh (a) terjadi pengalihan kode ke bahasa lain di kalimat yang berbeda, sedangkan contoh (b) terjadi pengalihan kode ke bahasa lain dengan batas antar klausa.

\section{c. Alih Kode Intra Kalimat (Intra-Sentential Switching) atau Campur Kode (Mixing Code)}

Alih kode intra kalimat secara sederhana didefinisikan sebagai alih kode yang terjadi pada unit-unit bahasa di dalam satu kalimat. Lebih lanjut, Romaine menjelaskan sebagai berikut:

"Intra-sentential switching involves switching within the boundaries of a clause or sentence, as well as within word boundaries" (Romaine, 2004:53). Kutipan tersebut menjelaskan bahwa alih kode intra kalimat dapat terjadi pada batas klausa, kalimat, dan bahkan kata.

Berkaitan dengan batas klausa dan kalimat tersebut di atas, terdapat dua unit bahasa yang terlibat di dalamnya, yakni: frasa dan kata. baster dan pengulangan kata. Berikut adalah contoh alih kode dari kedua unit bahasa tersebut: (a) "Aku pinjam book kamu ya.." , (b) "Kamu mau pesan orange juice, ga?". Contoh (a) merupakan alih kode intra kalimat dengan menggunakan unit kata, yakni pada kata 'book', dan (b) merupakan alih kode intra kalimat dengan menggunakan unit frasa, yakni pada frasa 'orange juice'.

Selain unit-unit bahasa yang telah dijelaskan di atas, pada alih kode intra kalimat juga terdapat dua komponen bentukan yang termasuk ke dalam alih kode jenis ini, yaitu: bentuk baster dan pengulangan kata (reduplikasi). Baster adalah hasil perpaduan dua unsur bahasa berbeda yang membentuk satu makna, contohnya: "Aku mau hot kopi aja, deh". Frasa 'hot kopi' disebut baster karena dibentuk dengan memadukan dua unsur bahasa yang berbeda. Sedangkan, pengulangan kata (reduplikasi) adalah penggunaan bentuk kata yang diulang dan disisipkan di dalam klausa ataupun kalimat, contohnya: "Kita walking-walking yuk". Pengulangan kata 'walking-walking' digunakan di dalam kalimat ini sebagai pengganti padanan kata 'jalan-jalan'; hal ini sering digunakan untuk hal yang bersifat jenaka dan dalam situasi yang tidak formal.

Selain unit bahasa dan komponen bentukan yang telah dijelaskan sebelumnya, pada kutipan yang diungkapkan Romaine juga mengungkapkan bahwa alih kode intra kalimat dapat juga terjadi pada batasan kata. Hal ini dapat saja terjadi ketika unsur pembentuk kata dari suatu bahasa dicampur kodekan dengan unsur pembentuk kata pada bahasa lainnya. Hal ini biasanya terjadi hanya untuk menimbulkan efek lucu dan kejenakaan; berikut adalah contohnya: “Jantungku hampir copot tadi, si supirman itu bawa angkotnya gila-gilaan". Di sini, kata 'supir' dicampur dengan 'man' yang merupakan salah satu unsur pembentuk kata bahasa Inggris yang menunjukkan jender pelaku kegiatan; biasanya 'man' digunakan di beberapa kata, seperti: policeman dan fireman. 


\section{Faktor penyebab Alih Kode dan Campur Kode}

Alih kode dan campur kode merupakan salah satu fenomena yang sering muncul dalam masyarakat multilingual. Faktor non linguistik ditemukan dalam wacana ini. Faktor tersebut adalah faktor sosial dan situasional. Menurut Suwito, faktor sosial adalah status sosial, pendidikan, umur, ekonomi dan jenis kelamin. Sedangkan faktor situasional adalah penutur/petutur, bahasa, latar belakang dan topik (Suwito, 1983).

Hal ini senada dengan yang diujarkan oleh Sankoff dalam Pride (1972:35):

"A number of lists of types of factors which influence speech behavior have been proposed, based broadly on those factors suggested by Jakobson (1960) and Hymes (1962). These lists usually include such factors as participants, topic, setting or context, channel, message form, mood or tone, and intentions and effects."

Berdasarkan keanekaragaman faktor penyebab alih kode dan campur kode yang diutarakan di atas, terdapat empat faktor dominan yang melatarbelakangi penggunaan alih kode dan campur kode, yaitu partisipan (penutur/petutur), latar belakang, topik, dan tujuan.

\section{a. Partisipan}

Partisipan yang terlibat adalah penutur dan lawan bicaranya (petutur). Partisipan ini sangat berpengaruh pada proses pemilihan bahasa yang digunakan. Tingkat keintiman dan hubungan sosial antara penutur dan petutur akan berujung pada cara atau sikap dalam berbahasa.

\section{b. Latar Belakang}

Ketika seorang penutur terlibat dalam suatu percakapan, dia akan mencoba beradaptasi pada situasi yang sedang dihadapi. Ada dua situasi yang melatarbelakangi, yaitu situasi formal dan informal.

\section{1). Situasi Formal}

Pada situasi formal, partisipan secara langsung ditekan untuk berbicara dengan menggunakan bahasa standar (formal). Dalam situasi ini, partisipan tidak cukup bebas dalam mengutarakan pikirannya.

\section{2). Situasi Informal}

Pada situasi informal, biasanya partisipan diberikan kebebasan menggunakan berbagai kode. Situasi ini menjadikan partisipan memiliki kesempatan (tidak terikat) untuk menggunakan jenis kode yang digunakan.

\section{c. Topik}

Dalam sebuah percakapan, berbagai topik dapat diujarkan dalam waktu yang bersamaan. Dengan latar belakang masyarakat multilingual, tidak jarang alih kode dan campur kode ditemukan muncul di antara pengguna bahasa. Alih kode dan campur kode dipilih seiring dengan topik yang dibicarakan.

\section{d. Tujuan}

Seorang multilingual biasanya akan mengalihkan atau mencampur kode yang digunakan dalam proses komunikasinya. Beberapa tujuan menjadi latarbelakang munculnya alih kode dan campur kode tersebut seperti saat percakapan ingin dilakukan dengan serius atau tidak serius (gurauan/candaan).

\section{TUJUAN DAN MANFAAT PENELITIAN}

\section{Tujuan Penelitian}

Adapun tujuan penelitian ini adalah sebagai berikut:

a. untuk menganalisis jenis alih kode dan campur kode yang ditemukan pada pola 
komunikasi antar dosen UNIKOM dalam aplikasi media sosial.

b. Untuk menganalisis faktor yang mempengaruhi terjadinya alih kode atau campur kode pada pola komunikasi dosen UNIKOM dalam aplikasi media sosial.

c. Untuk menjelaskan dampak yang ditimbulkan dengan pola komunikasi dalam aplikasi media sosial

\section{Manfaat Penelitian}

Penelitian ini diharapkan dapat memberi manfaat, baik secara teoritis maupun praktis. Secara teoritis, penelitian ini diharapkan dapat memberikan manfaat untuk pengembangan keilmuan dan pengetahuan di bidang linguistik, terutama sosiolinguistik. Adapun secara praktis, penelitian ini diharapkan dapat memberikan manfaat untuk mengembangkan kemampuan komunikasi yang efektif dalam menjalin silaturrahmi dan bersosialisasi di tengah masyarakat.

\section{METODE PENELITIAN}

\section{Metode dan Teknik}

\section{a. Metode}

Penelitian ini merupakan penelitian deskriptif kualitatif yang mengkaji fenomena kebahasaan dengan pendekatan sosiolinguistik. Pengumpulan data diperoleh dari lapangan dan pustaka. Analisis data menggunakan metode analisis deskriptif, yang mengacu pada fakta dan fenomena yang hidup secara empiris. Penyajian analisis data berupa narasi kata kata berdasarkan hasil dari analisis data yang diperoleh.

\section{b. Teknik}

Pengumpulan data adalah salah satu hal pokok yang harus dilakukan sebagai sebuah langkah awal dalam melakukan penelitian.
Adapun tujuan utama dari pengumpulan data adalah untuk mendapatkan data yang valid dan akurat. Berkenaan dengan penelitian ini, teknik pengumpulan data yang digunakan adalah observasi, membaca dan mencatat, serta membagikan kuesioner. Adapun sampel yang diambil dalam penelitian ini adalah percakapan dosen-dosen dan mahasiswa-mahasiswa UNIKOM di media sosial. Beberapa teknik yang dilakukan dalam penelitian ini adalah :

1). Memilih sumber data

Dalam melakukan penelitian ini, sumber data yang dibutuhkan haruslah valid dan akurat, serta tepat sasaran sesuai dengan topik penelitian yang diangkat.

2). Membaca keseluruhan data secara komprehensif dan menyeluruh.

3). Mengklasifikasikan data

Pada proses ini, data yang dipilih berupa kata, frasa, klausa dan kalimat yang berhubungan dengan alih kode dan campur kode. Selain itu, data juga diklasifikasikan ke dalam 4 faktor dominan yang melatar belakangi terjadinya komunikasi tsb. Pengklasifikasian data juga dilakukan pada dampak yang dihasilkan berdasarkan variasi pertanyaan di kuesioner.

4). Menganalisis data

Setelah proses klasifikasi data, data dianalisis dan dipaparkan dalam bentuk narasi kata kata.

\section{HASIL PENELITIAN DAN PEMBAHASAN}

\section{Jenis Alih Kode dan Campur Kode pada Pola Komunikasi antara Dosen dan Mahasiswa UNIKOM di Media Sosial}

Seperti yang telah dijelaskan di bagian sebelumnya, terdapat tiga jenis alih kode; alih kode tag (tag-switching), alih kode antar kalimat (inter-sentential) dan alih kode intra kalimat (intra-sentential) atau yang dikenal juga dengan campur kode. Adapun hasil penelitian menunjukkan terdapat 90 
dataterjadinya alih kode dan campur kode pada pola komunikasi antara dosen dan mahasiswa UNIKOM di media sosial.

Dari total data tersebut terdapat 129 kasus alih kode dan campur kode. Jenis alih kode yang paling banyak terjadi adalah alih kode intra kalimat atau yang dikenal juga dengan campur kode; persentase penggunaan jenis ini mencapai $82,2 \%$ atau setara dengan 106 kasus. Sebaliknya, jenis alih kode yang paling sedikit terjadi adalah alih kode tag; persentase penggunaannya hanya 0,8\% atau setara dengan 1 kasus. Sedangkan, jenis alih kode antar kalimat/klausa mencapai persentase $17 \%$ atau setara dengan 23 kasus. Pemaparan lebih detil mengenai setiap jenis alih kode tersebut akan dibahas pada sub bab berikut.

\section{a. Alih Kode intra kalimat (Campur Kode)}

Seperti yang telah dijelaskan di bab sebelumnya, alih kode intra kalimat merupakan alih kode yang terjadi di dalam satu kalimat yang sama. Oleh karena itulah, jenis alih kode ini juga disebut dengan campur kode. Pada penggunaannya, jenis alih kode ini dapat muncul dari beberapa tataran unit bahasa, yakni: kata, frasa, dan baster (frasa yang dibentuk dari dua atau lebih unit kata dari bahasa yang berbeda). Berikut adalah pemaparan hasil dan pembahasan mengenai alih kode jenis ini.

\section{Data 1.}

Himbauan dari prodi utk kalian visit job fair di miracle hr ini dan lusa

Pada data di atas terdapat satu kasus alih kode intra kalimat yang muncul dalam unit frasa, yakni: visit job fair (frasa verba).

\section{b. Alih Kode Tag}

Alih kode tag merupakan alih kode yang terjadi pada suatu ujaran dalam bahasa tertentu dengan menyisipkan tag atau yang dikenal dengan istilah 'pengukuh' dari bahasa yang lain.

Berkaitan dengan penelitian yang dilakukan, hanya terdapat satu kasus penggunaan alih kode tag, yakni yang terdapat pada data berikut:

\section{Data 69}

$J d$ skrg msh bs ikut seminar dlu, isn't it?

Pada data di atas terdapat kasus alih kode tag, yakni dengan menyisipkan pengukuh 'isn't it?'. Pada kasus ini, pernyataan yang muncul dalam bahasa Indonesia, diberi pengukuh di bagian akhir dalam bahasa Inggris.

\section{c. Alih Kode Antar Kalimat}

Alih kode antar kalimat merupakan alih kode yang terjadi dari satu bahasa ke bahasa lain pada kalimat atau klausa yang berbeda. Berkaitan dengan penelitian ini, terdapat tiga kasus penggunaan alih kode antar kalimat, yakni yang terdapat pada data-data berikut:

\section{Data 70}

Waalaikumsalam Mrs:)

Pada data di atas terdapat satu kasus alih kode antar kalimat, yakni penggunaan kalimat "Wassalamu'alaikum". Kalimat tersebut berasal dari bahasa Arab yang memiliki arti "dan semoga diberikan keselamatan atasmu, dan rahmat Allah serta berkah-Nya juga kepadamu."

\section{Bentuk Alih Kode dan Campur Kode pada Pola Komunikasi antara Dosen dan Mahasiswa UNIKOM di Media Sosial}

Bentuk alih dan campur kode terbagi menjadi dua, yakni: alih dan campur kode intern dan ekstern. Alih dan campur kode intern merupakan alih/campur kode yang terjadi antar bahasa daerah dalam suatu bahasa nasional; sedangkan, alih dan campur kode ekstern merupakan alih/ campur kode yang terjadi antara bahasa nasional dengan bahasa asing. Berkaitan dengan penelitian ini, yang dikategorikan sebagai bahasa nasional adalah bahasa Indonesia karena bahasa inilah yang digunakan secara formal di aplikasi media sosial tersebut, dan yang dikategorikan sebagai bahasa asing adalah bahasa 
Inggris, bahasa Arab, bahasa Spanyol, dan bahasa Italia yang familiar atau cukup dipahami oleh penutur dan mitra tutur di aplikasi tersebut. Adapun hasil penelitian menunjukkan dari 129 kasus alih dan campur kode yang terjadi, terdapat 9,3\% penggunaan bentuk alih dan campur kode intern atau setara dengan 12 kasus; sedangkan, bentuk ekstern mencapai $90,7 \%$ atau setara dengan 117 kasus. Pemaparan detil mengenai hasil dan pembahasan mengenai bentuk alih dan campur kode yang ditemukan pada penelitian akan dibahas di sub bab berikut ini.

\section{a. Alih Kode dan Campur Kode Intern}

Pemaparan pada sub bab mengenai bentuk alih kode dan campur kode ini mengacu pada data yang sama dengan pembahasan mengenai jenis alih kode dan campur kode pada sub-sub bab sebelumnya.

Berikut adalah pembahasan mengenai bentuk alih dan campur kode dimaksud.

\section{Data 3}

Alih dan campur kode intern dari bahasa Indonesia ke bahasa daerah. Penutur menggunakan kata 'ngabibita' yang bersumber dari bahasa Sunda di dalam kalimat yang dituturkannya.

\section{b. Alih Kode dan Campur Kode Ekstern}

Pada data 1 terdapat alih dan campur kode ekstern dari bahasa Indonesia ke bahasa Inggris. Penutur menggunakan frasa 'visit job fair' di dalam kalimat yang dituturkannya.

Pada data 2 terdapat alih dan campur kode ekstern dari bahasa Indonesia ke bahasa Inggris. Penutur menggunakan kata 'open' di dalam kalimat yang dituturkannya.

\section{Faktor Penyebab Alih kode}

Berdasarkan pemaparan diatas ada 90 kasus alih kode dan campur kode yang terdapat dalam data.Terjadinya alih kode dan campur kode seperti yang sudah dipaparkan dalam tinjauan pustaka memiliki 4 faktor dominan. Keempat faktor terjadinya alih kode dan campur kode tersebut akan dipaparkan pada subbab berikut.

\section{a. Partisipan (penutur/ petutur)}

Partisipan adalah pihak yang terlibat dalam komunikasi yakni penutur dan lawan bicaranya (petutur). Partisipan memiliki pengaruh yang besar dalam menentukan pemilihan bahasa, tetapi partisipan sendiri sangat dipengaruhi oleh tingkat keintiman dan juga hubungan sosial antara yang berbicara (penututur) dan lawan bicaranya (petutur).

Dalam analisis alih kode dan campur kode dalam pola komunikasi dosen dan mahasiswa di media sosial jelas bahwa partisipan adalah dosen dan mahasiswa. Tetapi tingkat kedekatan mahasiswa tersebut dan dosen tetap mempengaruhi cara dan sikap dalam berbahasa. Tetapi, hubungan sosial sebagai pengajar dan siswa yang diajar tetap mempengaruhi cara mahasiswa berbicara seperti penggunaan sapaan mam kepada dosen dan juga tetap bersikap sopan dalam penggunaan bahasanya.

\section{b. Latar Belakang}

Latarbelakang adalah situasi yang melatarbelakangi terjadinya pembicaraan. Setiap penutur akan beradaptasi dengan situasi ketika terlibat dalam sebuah percakapan. Latar belakang dibagi menjadi dua bagian 
besar yakni formal dan informal. Pada situasi formal partisipan dituntut untuk mengggunakan bahasa standar (baku); sedangkan, dalam situasi informal, partisipan bisa menggunakan bahasa pergaulan atau kata-kata tidak baku. Pada situasi ini partisipan diberi kebebasan untuk menggunakan berbagai kode.

Dalam pola komunikasi antara dosen dan mahasiswa UNIKOM di media sosial, situasi yang dibangun ini lebih informal karena dipengaruhi oleh media yang digunakan yakni group media sosial.Media sosial memungkinkan suasana yang lebih akrab dalam komunikasi antara dosen dan mahasiswa.Ruang media sosial yang berbeda dari ruang kelas sehingga suasana infomal bisa terbangun meskipun dalam ranah yang berhubungan dengan akademik.Situasi yang melatar belakangi komunikasi dalam penelitian ini juga menekankan kedekatan antara penutur dan petutur.

\section{c. Topik}

Munculnya alih kode dan campur kode juga dipengaruhi oleh topik yang dibicarakan. Dalam pola komunikasi dosen dan mahasiswa UNIKOM di media sosial, topik yang dibicarakan berfokus pada kegiatan akademik atau informasi yang berhubungan dengan akademik.Selain itu, ada juga topik yang tidak berhubungan dengan akademik.

Informasi yang berhubungan dengan akademik bisa menyebabkan alih kode dan campur kode karena kebutuhan leksikal, seperti istilah yang berhubungan dengan akademik tertentu misalnya nama mata kuliah seperti reading atau istilah lain yang digunakan open book, oral test. Tetapi disisi lain, topik yang tidak berhubungan dengan akademik juga bisa menyebabkan alih kode dan campur kode misalnya dengan mencapurkan bahasa Indonesia dengan bahasa daerah dengan maksud agar pembicaraan menjadi lebih jenaka .

\section{d. Tujuan}

Alih kode dan campur kode terjadi disebabkan oleh tujuan tertentu. Ada delapan tujuan penggunaan alih kode dan campur kode, yakni untuk: (a) memperhalus dan atau menguatkan permintaan ataupun perintah, (b) mengeliminasi keambiguan, (c) memberikan penekanan pada bagian tertentu dari ungkapan, (d) menunjukkan hubungan yang informal atau kedekatan, (e) menimbulkan efek jenaka atau humor, (f) penggunaan kutipan langsung, (g) kebutuhan leksikal, dan (h) sebagai strategi perbaikan dalam komunikasi.

Dalam pola komunikasi dosen dan mahasiswa UNIKOM di media sosial, dari total 90 data terjadinya alih dan campur kode, ada lima tujuan alih dan campur kode yang ditemukan, yakni: kebutuhan leksikal sebanyak 49 kasus atau 51,04\%, penekanan dari ungkapan sebbanyak 11 kasus atau 11,5\%, menunjukkan hubungan informal atau kedekatan sebanyak 24 kasus atau $25 \%$, memperhalus permintaan sebanyak $4,16 \%$, dan menimbulkan efek jenaka atau humor sebanyak 8 kasus atau $8,3 \%$. Adapun penjelasan detil mengenai hal tersebut dapat dilihat di paragraf-paragraf berikut ini.

\section{Dampak yang ditimbulkan dengan pola komunikasi dalam aplikasi media Sosial}

Berdasarkan hasil dari analisis data dan kuesioner yang disebar antar dosen dan mahasiswa di lingkungan Universitas Komputer Indonesia, didapatkan hasil sebagai berikut :

a. Baik penutur maupun petutur dalam hal ini dosen dan mahasiswa pernah menggunakan media sosial. Jumlah yang mencapai $100 \%$ ini, menunjukkan bahwa sosial media sudah menjadi media yang biasa digunakan baik oleh dosen maupun mahasiswa. Namun, hasil ini belum bisa menunjukkan tingkat frekuensi 
penggunaan media tersebut.

b. Baik penutur maupun petutur dalam hal ini dosen dan mahasiswa menggunakan bahasa Indonesia. Meskipun komunikasi yang terjadi didominasi oleh bahasa Indonesia, namun tetap tidak ditemukan $100 \%$ komunikasi yang murni dengan menggunakan bahasa Indonesia saja.

Beberapa faktor yang menjadi penyebabnya antara lain adalah banyak bahasa asing yang sudah diserap ke bahasa Indonesia, situasi informal yang lebih mendominasi dalam komunikasi menggunakan media sosial.

\section{Data 64}

Klo masalah konten mah urusan editor.Kamu mah urusan tata bahasa dan korespondensi.Klo mau masukin lamaran jgn ragu. Ada saya di situ yg bakal jd salah satu supervisor kamu. JAP adalah jurnalnya dokter2 anastesi alias ahli membius.

c. Baik penutur maupun petutur dalam hal ini dosen dan mahasiswa menggunakan bahasa selain bahasa Indonesia (bahasa Inggris, bahasa daerah (Sunda), bahasa Arab). Penggunaan beberapa bahasa dalam sebuah komunikasi muncul sebanyak $100 \%$ dari data yang dikumpulkan.

Data 3

It means, si lucu lgi ngabibita ma'am ahahah

Data 16

Jek mah udh jatuh love sma syifa mam

d. Baik penutur maupun petutur dalam hal ini dosen dan mahasiswa merasakan manfaat yang berhubungan dengan proses belajar mengajar, seperti perasaan berani mengeluarkan pendapat/ berargumen, kemudahan mendapat informasi, dll.

Data 1.

Himbauan dari prodi utk kalian visit job fair di miracle hr ini dan lusa

Data di atas menunjukkan kemudahan dalam menyampaikan sebuah infromasi, sehingga bisa segera ditindak lanjuti

\section{Data 6}

Mam ituulen ? Is it right?

Data di atas secara implisit bisa dimaknai bahwa bagaimana seorang mahasiswa berani mengutarakan pendapatnya pada seorang dosen.

e. Secara ekonomi, penggunaan media sosial ini tidak menjadi beban. Meskipun tidak langsung memberi kontribusi pada tujuan penelitian ini, namun dari hasil kuesioner menunjukkan bahwa penggunaan media sosial seperti Line, Whatsapp, Facebook, dan semacamnya tidak menjadikan kendala (secara finansial) bagi mahasiswa dan dosen dalam melalukan komunikasi di luar jam perkuliahan.

\section{KESIMPULAN}

Berdasarkan hasil analisis dari data yang diperoleh, dapat disimpulkan bahwa terdapat tiga jenis alih kode; alih kode tag (tag-switching), alih kode antar kalimat (inter-sentential) dan alih kode intra kalimat (intra-sentential) atau yang dikenal juga dengan campur kode. Adapun hasil penelitian menunjukkan terdapat 90 data terjadinya alih kode dan campur kode pada pola komunikasi antara dosen dan mahasiswa UNIKOM di media sosial. Dari total data tersebut terdapat 129 kasus alih kode dan campur kode. Jenis alih kode yang paling banyak terjadi adalah alih kode intra kalimat atau yang dikenal juga dengan campur kode; persentase penggunaan jenis ini mencapai $82,2 \%$ atau setara dengan 106 kasus. Sebaliknya, jenis alih kode yang paling sedikit terjadi adalah alih kode tag; persentase penggunaannya hanya 0,8\% atau setara dengan 1 kasus. Sedangkan, jenis alih kode antar kalimat/klausa mencapai persentase $17 \%$ atau setara dengan 23 kasus. 
Faktor dominan yang muncul dalam data yang dianalisis meliputi partisipan, latar belakang, topik dan tujuan. Keempat faktor ini memberi kontribusi pada pola komunikasi antar dosen dan mahasiswa dengan menggunakan media sosial. Partisipan dalam penelitian ini adalah dosen dan mahasiswa. Faktor kedekatan antara dosen dan mahasiswa dan juga latar formal atau informal mempengaruhi cara dan sikap bahasa. Topik komunikasi dalam pola komunikasi dosen dan mahasiswa ini dibagi dua yakni mengenai akademik dan non akademik. Sementara itu, dari total 90 data terjadinya alih dan campur kode, ada lima tujuan alih dan campur kode yang ditemukan, yakni: kebutuhan leksikal sebanyak 49 kasus atau $51,04 \%$, penekanan dari ungkapan sebbanyak 11 kasus atau 11,5\%, menunjukkan hubungan informal atau kedekatan sebanyak 24 kasus atau $25 \%$, memperhalus permintaan sebanyak $4,16 \%$, dan menimbulkan efek jenaka atau humor sebanyak 8 kasus atau $8,3 \%$.

Dampak yang dihasilkan menunjukkan adanya banyak manfaat dari penggunaan media sosial ini, antara lain baik penutur maupun petutur dalam hal ini dosen dan mahasiswa bisa mendapatkan informasi seputar proses belajar mengajar, dengan cepat dan jelas. Selain itu juga menumbuhkan keberanian lebih pada mahasiswa untuk berkomunikasi dengan dosen baik pada jam perkuliahan ataupun di luar jam tsb.

\section{SARAN}

Penelitian ini diharapkan bisa memberikan kesadaran pengguna bahasa dalam upaya untuk kesadaran berbahasa. Penggunaan bahasa informal lebih sering digunakan baik oleh dosen maupun mahasiswa di media sosial. Dampak lebih jauh dengan penggunaan bahasa secara bebas ini dapat dijadikan topik untuk penelitian selanjutnya dimana kebebasan berbahasa dan kebebasan berwacana dimungkinkan dapat lebih berdampak positif atau negatif.

\section{DAFTAR PUSTAKA}

Chloros, Penelope Gardner. (2009). Code Switching. Cambridge: Cambridge University Press.

Ohoiwutun, Paul. (2007). Sosiolinguistik: Memahami Bahasa dalam Konteks Masyarakat dan Kebudayaan. Jakarta: Kesaint Blanc.

Rahardi, K. (2001). Sosiolinguistik, Kode dan Alih Kode. Yogyakarta: Pusataka Pelajar.

Romaine, Suzanne. (2004). LanguageContact Studies. Sosiolinguistics: An International Handbook of the Science of Language and Society, 2nd Edition. Berlin: Walter de Gruyter.

Saville-Troike, Muriel. (2003). The Ethnography of Communication: An Introduction 3rd Edition. Oxford: Blackwell Publishing 
\begin{tabular}{l|l} 
Majalah IImiah UNIKOM & Vol.14 No. 2
\end{tabular}

\begin{tabular}{l|l} 
H a I a m a n & 184
\end{tabular} 